\title{
Larvicidal Activity of Essential Oils from the Leaves and Fruits of Nutmeg (Myristica fragrans Houtt) Against Aedes aegypti (Diptera: Culicidae)
}

\author{
Anne Carolina*, Maman Maman
}

Department of Forest Products, Faculty of Forestry, Bogor Agricultural University (IPB),Jl. Lingkar Kampus IPB Dramaga Bogor, 16680, West Java, Indonesia

A R T I C L E I N F O
Article history:
Received 14 March 2016
Accepted 14 July 2016
Available online, ISSN: 2148-127X

Keywords:

Aedes aegypti

Essential oil

Larvicides

$\mathrm{LC}_{50}$

Myristica fragrans \begin{abstract}
A B S T R A C T
The aim of this research was to examine the larvicidal activity of essential oil (EO) extracted from nutmeg (Myristica fragrans Houtt) leaves and fruits by steam distillation, and to analyze its chemical compounds. The EO yield of nutmeg leaves and fruits collected from the same tree was $0.66 \%$ and $0.30 \%$, respectively. Larvicidal tests with the EO were carried out against Aedes aegypti (L.) (Diptera: Culicidae). The concentrations of nutmeg EO used for the larvicidal assay were 50,100,150,200, and $250 \mu \mathrm{g} / \mathrm{mL}$. The results showed that fruit oil was more toxic than the leaf oil. $\mathrm{LC}_{50}$ values of leaf and fruit EOs were 133.8 and $110.1 \mu \mathrm{g} / \mathrm{mL}$, respectively. The chromatogram of GC-MS showed that the chemical components in nutmeg leaf and fruit EOs were dominated by $\alpha$-pinene, sabinene, $\beta$-pinene, delta-3-carene, limonene, $\beta$-phellandrene, $\alpha$-terpinolene, linalool, safrole, croweacin, and myristicin.
\end{abstract}

${ }^{*}$ Corresponding Author:

E-mail: a_caroline@ipb.ac.id

\section{Introduction}

Nutmeg (Myristica fragrans Houtt) (Myristicaceae) is a kind of forest product spices that is used throughout the world. It can be used for food, beverage and cosmetics. This plant is originated from Banda Islands of Eastern Indonesia. It is one of the major export commodities, about of $75 \%$ of the world nutmeg was supplied from Indonesia (Kementerian Pertanian RI, 2013). The fruit is known as a herb plant that has economic value and versatility. Traditionally, nutmeg widely used as a seasoning to flavor dishes. The nutmeg essential oil (EO) from its seeds and leaves can be used as a medicine to relieve indigestion and pain (Wahyuni et al., 2008). The previous study reported that nutmeg seed-derived materials exhibited potent lethal activity against female Blattella germanica (Dictyoptera: Blattidae) (Jung et al., 2007). Utilization of natural compounds derived from nutmeg to control insect will also greatly assist in controlling disease spread out by mosquitoes.

An infectious disease caused by the dengue virus and spread through the bite of an Aedes aegypti (L.) (Diptera: Culicidae) mosquito is dengue fever. The dengue virusbased infections are transmitted by the bite of an infected Aedes mosquito. Mosquitoes become infected when they bite infected humans, and later transmit infection by biting other people. In Indonesia, dengue has become a public health problem during the past 41 years. Dengue vector control in almost all countries and endemic areas are not well targeted, it is not sustainable and yet able to break the chain of transmission. This is due to the method applied not refer to the information about vector, in addition to still rely on the use of insecticides and larvicides by spraying or fumigation (Sukowati, 2010).

The use of synthetic insecticides is very harmful to the environment and human health because their residues are left in the environment. NICC in Cavalcanti et al., (2004) reported that Temephos, an insecticide used in mosquito control, can cause headaches, irritability, and memory loss. It can get into the food chain and accumulate in it. Therefore, it is necessary to develop the insecticides those are safe for humans and the environment.

It has been found the materials that could potentially be developed as a natural insecticide extracted from several plant species. The EO of Eucalyptus camaldulensis Dehn. and E. urophylla S.T Blake (Myrtaceae) showed larvicidal activity against $A$. aegypti with $\mathrm{LC}_{50}$ values, respectively, 31.0 and $95.5 \mu \mathrm{g} / \mathrm{mL}$ (Cheng et al., 2009). Myristicin that was extracted from nutmeg seed kernel is promising as alternatives to 
available larvicides against Culex pipiens L. (Dip.: Culicidae) and A. aegypti (Abou-elnaga, 2014). Meanwhile, in the present time, the use of EO from nutmeg leaves and fruits is relatively lower than those from its seeds. Therefore, in this research, the EO derived from nutmeg leaves and fruits were produced by steam distillation. Their potential use as bio-larvicides against third instar larvae of A. aegypti was investigated.

\section{Materials and methods}

\section{Plant Materials}

Nutmeg leaves and fruits were obtained from Bogor, West Java Indonesia on the midle of August. The A. aegypti eggs were obtained from the Faculty of Veterinary, Bogor Agricultural University (IPB), Indonesia.

Preparation of raw materials and steam distillation

Nutmeg leaves were cleaned from branches; the fruits were cut into 4 pieces. They were air-dried to remove water. The leaves and fruits were weighed and placed in distillation flask. The processes were taken place during 2 hours. The collected EO were added by anhydrous sodium sulfate, weighed and stored in a sealed vial dark colored at $4^{\circ} \mathrm{C}$ for further analysis. The yield percentage of EO was determined using the formula described below.

$$
\text { Yield }(\%)=\frac{\text { Amount of essential oil recovered }(\mathrm{g})}{\text { Amount of plant material distilled }(\mathrm{g})}
$$

\section{Aedes Aegypti Culture}

The mosquito larvae were prepared by hatched the eggs in an aqueous medium. The eggs were hatched within $\pm 24 \mathrm{~h}$. The mosquito larvae grew to reach the third instar at the age of 4 days. The test was conducted against third instar larvae of A. aegypti.

\section{Larvicidal Assay}

Larvicidal activity assay of nutmeg EO referred to a WHO standard method (2005) with a slight modification, at the level of concentration of leaves and fruits EO, respectively, 50, 100, 150, 200 and $250 \mu \mathrm{g} / \mathrm{mL}$. Observation on larval mortality was recorded after $24 \mathrm{~h}$ of exposure. Probit analysis was used to determine the lethal concentrations $\left(\mathrm{LC}_{50}\right.$ and $\left.\mathrm{LC}_{90}\right)$.

\section{Analysis of Chemical Compound}

The EO was quantitatively analyzed by Agilent Technologies $6890 \mathrm{~N}$ series of GC-MS instrument employing the following condition: capillary column with a maximum temperature of $350^{\circ} \mathrm{C}$ for $35 \mathrm{~min}$, injector temperature of $250^{\circ} \mathrm{C}$, detector temperature of $250^{\circ} \mathrm{C}$, and the initial temperature of the column of $100^{\circ} \mathrm{C}$ with an increase of $15^{\circ} \mathrm{C}$ per minute to $350^{\circ} \mathrm{C}$. Identification of compounds was done by fitting the mass spectrum and the ion fragmentation of compound with the data in the WILLEY $9^{\text {th }}$ library.

\section{Results and Discussion}

The Distillation Yield and Larvicidal Activity of Nutmeg Oil

Nutmeg EO was extracted by steam distillation method with a yield of 0.66 and $0.30 \%$ from the leaves and the fruits, respectively. Toxicity tests with the EO from nutmeg leaves and fruits were conducted against third instar A. aegypti larvae. The results showed an increase in the mortality of larvae due to the increase in concentration of EO added (Table 1).

Mortality percentage is defined as the ratio of dead larvae after 24 hours of EO exposure against the 20 larvae tested. Furthermore, probit analysis showed that the EO from fruits with a $\mathrm{LC}_{50}$ value of $110.1 \mu \mathrm{g} / \mathrm{mL}$ had better larvicidal activity when compared to that from leaves of the same tree (Figure 1). The content of the active chemical compounds in nutmeg oil was supposed having a role in the death of the mosquito larvae.

Table 1 The mortality of Aedes aegypti larvae after 24 hours of essential oil exposure $(\mathrm{n}=20)$

\begin{tabular}{l|cc}
\hline \multirow{2}{*}{ Concentration of tested materials $(\mu \mathrm{g} / \mathrm{mL})$} & \multicolumn{2}{|c}{ Mortality $(\%)$} \\
\cline { 2 - 3 } & Nutmeg leaves essential oils & Nutmeg fruits essential oils \\
\hline 0 & 0 & 0 \\
50 & 11.67 & 21.67 \\
100 & 26.67 & 46.67 \\
150 & 66.67 & 81.67 \\
200 & 88.33 & 91.67 \\
250 & 91.67 & 93.33 \\
Abate & 100.00 & 100.00 \\
\hline
\end{tabular}




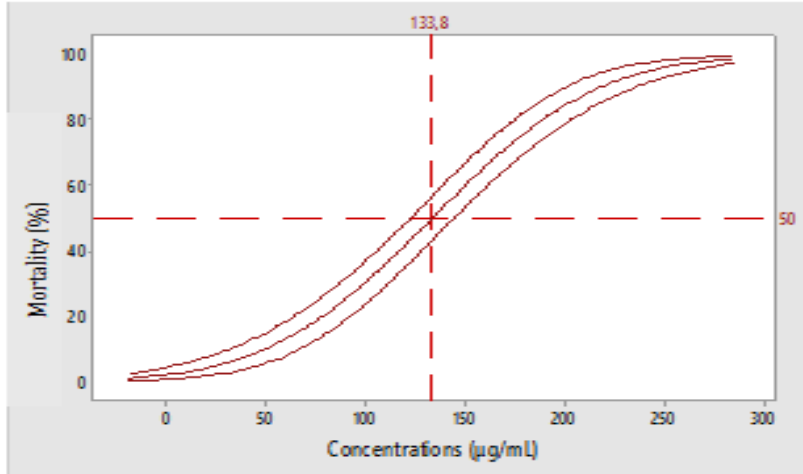

(a)

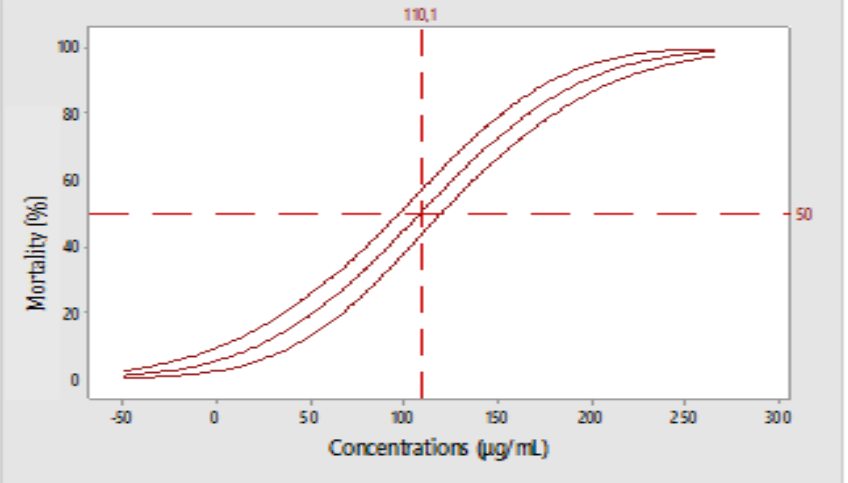

(b)

Figure 1 Concentration relation of (a) Nutmeg leaf essential oils, (b) Nutmeg fruit essential oils against the mortality of Aedes aegypti larvae based on Probit analysis.

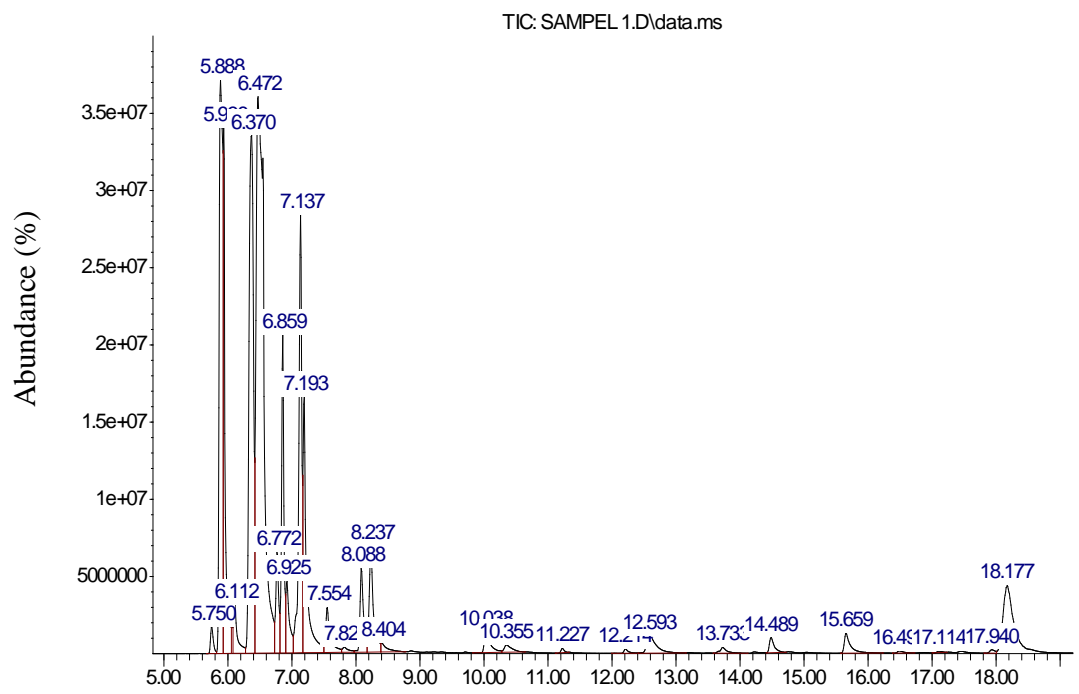

Time (minutes)

Figure 2 GC-MS Chromatogram of nutmeg leaf essential oil.

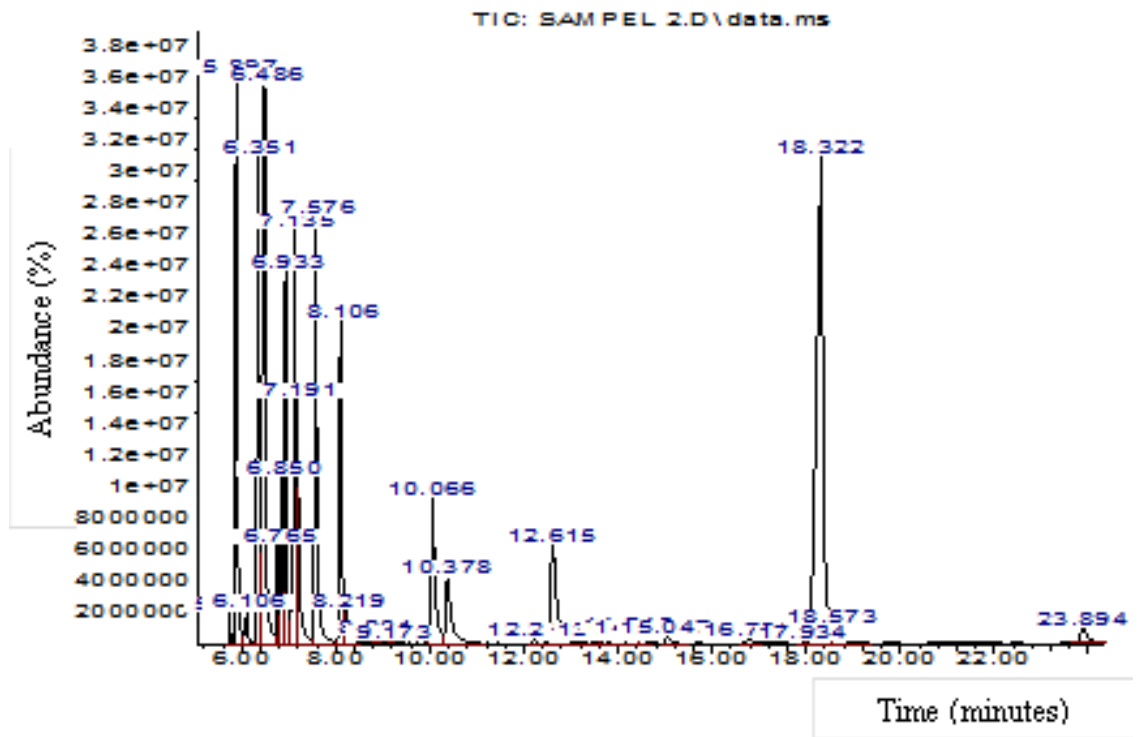

Figure 3 GC-MS Chromatogram of nutmeg fruit essential oil. 
Table 2 Major chemical compounds of nutmeg essential oils based on GC-MS analysis

\begin{tabular}{cc|ll}
\hline NLE & NFE & \multicolumn{1}{|c}{ Compound } & \multicolumn{1}{c}{ Bioactivity } \\
\cline { 1 - 2 } $\mathrm{C}(\%)$ & $\mathrm{C}(\%)$ & \multicolumn{1}{|c}{ Antimicrobial, antibacteril (Stahl 1985, Nurdjannah 2007) } \\
18.98 & 8.74 & $\alpha$-Pinene & Antimcrobial (Zhang et al. 2014) \\
14.35 & 7.09 & Sabinene & Antimicrobial \& antibacterial (Stahl 1985, Nurdjannah 2007) \\
27.82 & 13.69 & $\beta$-Pinene & Antimicrobial (Tarek et al. 2014) \\
4.64 & 2.09 & Delta-3-Carene & Antibacterial (Ketaren 1985) \\
8.05 & 6.41 & Limonene & Cytotoxic \& antibacterial (Boehme 2008) \\
5.76 & 4 & $\beta$-Phelandrene & Antiseptic, antiviral (Ketaren 1985) \\
2.8 & - & Linalool & Antimicrobial (Stahl 1985) \\
1.86 & 6.06 & $\alpha-$-Terpinolene & Antimicrobial \& antibacterial (Stahl 1985, Nurdjannah 2007) \\
1.06 & 4.58 & Safrole & Antibacterial (Khalfalah et al. 2011) \\
- & 23.03 & Croweacin & Antimicrobial (Stahl 1985, Shulgin 1967) \\
4.74 & 0.83 & Myristicin & .
\end{tabular}

NLE: Nutmeg leaf essential oil; NFE: Nutmeg fruit essential oil; C\%: Concentration (\%)

\section{Chemical Composition of Nutmeg EO}

Based on the results of GC-MS analysis, a total of 28 components were identified in the nutmeg leaf oil and 29 components in nutmeg fruit oil (Figures 2 and 3). This indicated that nutmeg EO derived from different parts of the plant contains chemical compounds with different compositions. Bioactive compounds of nutmeg leaf and fruit EOs were presented in Table 2. Some of the compounds contained in nutmeg oil with relatively large concentrations such as $\alpha$-pinene, $\beta$-pinene, sabinene, limonene, croweacin, and myristicin were assumed to contribute to larvicidal activity of nutmeg oil against $A$. aegypti.

GC-MS chromatogram showed that myristicin was found about $4.74 \%$ in nutmeg leaf oil and $0.83 \%$ in its fruit oil. Meanwhile, croweacin was found in the highest concentration $(23.03 \%)$ in the fruit oil. The Indonesian National Standard stated that the quality of nutmeg EO is determined by the content of myristicin, with a minimum value of 5\% (BSN, 2006).

Myristicin is a psychoactive compound. Results suggested that the anti-inflammatory action is due to the myristicin present in nutmeg oil (Asgarpanah and Kazemivash, 2012). The insecticidal activity of myristicin has also been reported by Srivastava et al., (2001). They showed antimetabolic activity against fouth instar larvae of Spilarctia oblique (Walk.) (Lepidoptera: Arctiidae) after $24 \mathrm{~h}$, the $\mathrm{LD}_{50}$ was $104 \mu \mathrm{g} /$ larvae.

The study showed that croweacin presented only in the fruit oil (Table 2). Croweacin was also found as the main constituent of the essential oil of the Australian shrub Eriosternon crowei F. Muell (de Oliveira et al., 1997). Meanwhile, croweacin and $\rho$-cymene were identified as a major compound in the EO of Inula crithmoides L. (Asteraceae) in Algeria. This EO was moderately active against Staphylococcus aureus (MRSA) ATCC 27853 (Staphylococcaceae) (Ramdani et al., 2015). Khalfallah et al. (2011) showed that the essential oil of Ammi visnaga L. (Apiaceae) is mainly characterized by the presence of isobutyl isobutyrate, linalool, 2,2-dimethylbutanoic acid, thymol, bornyl acetate and croweacin as major components. It possessed the antibacterial activity against Escherichia coli (Migula,
1895) Castellani and Chalmers, 1919 (Enterobacteriaceae), Pseudomonas aeruginosa (Schröter, 1872) Migula, 1900 (Pseudomonadaceae) and Klebsiella pneumoniae (Schroeter 1886) Trevisan, 1887 (Enterobacteriaceae) strains. The oil of Crowea saligna Andrews (Rutaceae) contained croweacin (84-94\%) (Brophy et al., 1997).

Croweacin is an allyl benzene compound. It is a derivative of safrole with the addition of a methoxy group on the benzene ring. It is also a positional isomer of myristicin. Structural similarities of myristicin and croweacin to classical hallucinogenic compounds (e.g. mescaline) suggest that these compounds may act as a serotonin receptor agonist and hallucinogenic compound (Barceloux, 2009).

Probit analysis of the results from the larvicidal tests showed that fruit EO with $\mathrm{LC}_{50}$ value of $110.1 \mu \mathrm{g} / \mathrm{mL}$ had better larvicidal activity when compared to leaf EO derived from the same tree (Figure 1). The content of the active chemical compounds in nutmeg oil was supposed having a role in the death of the mosquito larvae.

\section{References}

Abou-elnaga ZS. 2014. Insecticidal bioactivity of eco-friendly plant origin chemicals against Culex pipiens and Aedes aegypti (Diptera: Culicidae). Journal of Entomology and Zoology Studies, 2(6): 340-347.

Asgarpanah J, Kazemivash N. 2012. Phytochemistry and pharmacologic properties of Myristica fragrans Hoyutt:: A review. African Journal of Biotechnology, 11(65): 1278712793.

BSN. 2006. Minyak Pala (Myristica fragrans). Standar Nasional Indonesia 06-2388. Jakarta: Badan Standardisasi Nasional (In Indonesian)

Barceloux DG. 2009. Medical Toxicology of Natural Substances: Foods, Fungi, Medicinal Herbs, Toxic Plants, and Venomous Animals. Hoboken, New Jersey: John Wiley \& Sons. Pp. 67-70.

Boehme AK, Noletto JA, Haber WA, Setzer WN. 2008. Bioactivity and chemical composition of the leaf essential oils of Zanthoxylum rhoifolium and Zanthoxylum setulosum from Monteverde, Costa Rica. Natural Product Research, 22(1): 3136.

Brophy JJ, Goldsack RJ, Punruckvong A, Forster PI, Fookes CJR. 1997. Essential oils of the genus Crowea (Rutaceae). Journal of Essential Oil Research 9(4): 401-409. 
Cavalcanti ESB, de Morais SM, Lima MAA \& Santana EWP. 2004. Larvicidal activity of essential oils from Brazilian plants against Aedes aegypti L. Mem Inst Oswaldo Cruz 99(5): 541-544.

Cheng SS, Huang CG, Chen YJ, YU JJ, Chen WJ, Chang ST. 2009. Chemical compositions and larvicidal activities of leaf essential oils from two eucalyptus species. Bioresource Technology 100(1): 452-456.

de Oliveira SBV, da-Cunha EVL, de Oliveira Chaves MC, Gray AI. 1997. Croweacin from Piper marginatum • Biochemical Systematics and Ecology, 25(5), 471-472.

Jung WC, Jang YS, Hieu TT, Lee CK, Ahn YJ. 2007. Toxicity of Myristica fragrans seed compounds against Blattella germanica (Dictyoptera: Blattellidae). Journal of Medical Entomology 44(3): 524-9.

Kementerian Pertanian Republik Indonesia. 2013. Pengembangan Tanaman Pala ( New Inisiatif ) Tahun 2013. Jakarta: Dirjen Perkebunan Kementan RI (In Indonesian).

Ketaren S. 1985. Pengantar Teknologi Minyak Atsiri. Jakarta: Balai Pustaka (In Indonesian).

Khalfallah A, Labed A, Semra Z, Ai KB, Kabouche A, Touzan R, Kabouche Z. 2011. Antibacterial activity and chemical composition of the essential oil of Ammi visnaga L. (Apiaceae) from Constantine, Algeria. International Journal of Medicinal and Aromatic Plants 1(3): 302-305.

Nurdjannah N. 2007. Teknologi Pengolahan Pala. Bogor: Badan Penelitian dan Pengembangan Pertanian (In Indonesian).
Ramdani M, Bousnina Y, Djoudi A, Chalard P, Figueredo G, Lograda T. 2015. Chemical composition, antibacterial activity and chromosome number of Algerian populations of Inula crithmoides L. Journal of Science 5(11): 976-982.

Shulgin AT. 1967. Psychotropic phenylisopropylamines derived from Apiole and Dillapiole. Nature 215: 1494-95.

Srivastava S, Gupta MM, Prajapati V, Tripathi AK, Sushil Kumar. 2001. Insecticidal activity of myristicin from Piper mullesua. Pharmaceutical Biology 39(3):226-229.

Stahl E. 1985. Analisis Obat Secara Kromatografi dan Mikroskopi. Padmawinata K \& Soediro I (Translators). Bandung: Institut Teknologi Bandung. Pp. 3-17 (In Indonesian).

Sukowati S. 2010. Masalah vektor demam berdarah dengue (DBD) dan pengendaliannya di Indonesia in Pangribowo S, Tryadi A (ed). Buletin Jendela Epidemiologi 2 (In Indonesian).

Tarek N, Hassan HM, Abdelghani SMM, Radwan IA, Hammouda O. 2014. Comparative chemical and antimicrobial study of nine essential oils obtained from medicinal plants growing in Egypt. Journal of Basic and Applied Sciences 53(1): 65-103.

Wahyuni S, Hadad EA, Suparman, Mardiana. 2008. Keragaman produksi plasma nutfah pala (Myristica fragrans) di KP Cicurug. Buletin Plasma Nutfah 14(2): 68-75 (In Indonesian).

WHO. 2005. Guidelines for Laboratory and Field Testing of Mosquito Larvicides. WHO/CDS/WHOPES/GCDPP/2005.13. http://apps.who.int/iris/bitstream/10665/69101/1/WHO_CDS_ WHOPES_GCDPP_2005.13.pdf.

Zhang H, Liu Q, Cao Y, Feng X, Zheng Y, Zou H, Liu H, Yang H, Xian M. 2014. Microbial production of sabinene a new terpenebased precursor of advanced biofuel. Microbial Cell Factories 13: 20 . 